\title{
Emlékezés Paál Hubára (1942-2021)
}

\author{
SZABÓ László Gy. \\ 7623 Pécs, Semmelweis u. 11.; szabol@gamma.ttk.pte.hu
}

Elfogadva: 2021. november 5 .

Kulcsszavak: agrobotanika, citológia, Tápiószele, tudományszervezés

A mindig vidám, optimista barátom földi pályafutása 2021. október 16-án, 79 éves korában véget ért. Többet nem hív fel telefonon, hogy méltassa „grafomán hajlamom" egy-egy újabb termékét, írásaimat, emlékezéseimet szeretett Mestereimről, Barátaimról, Példaképeimről.

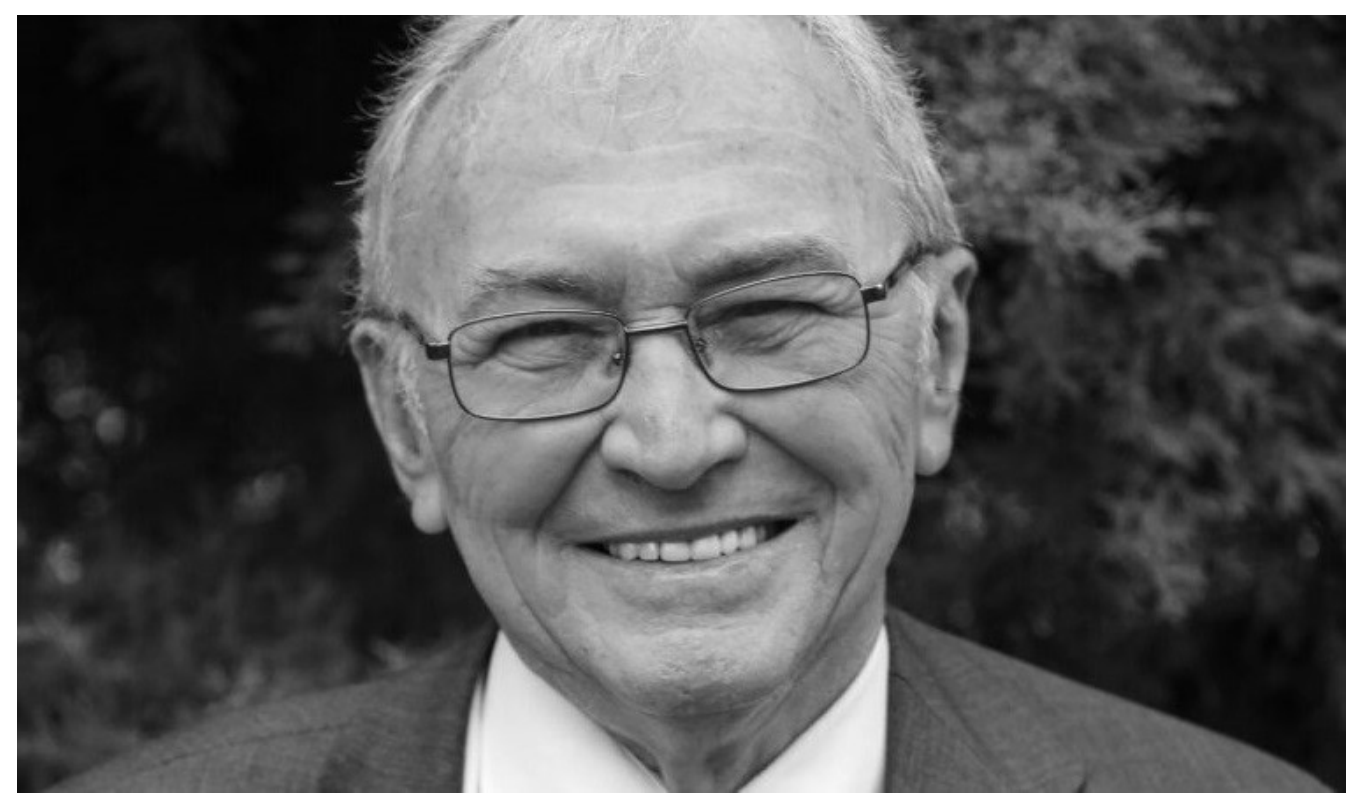

Paál Huba Lajosmizsén született 1942. május 14-én. Édesapja biológiatanárnak készült, de egyetemi tanulmányait nem fejezte be, a család érdekében pályát módosított. 1955-ben a család Pusztaszabolcsra költözött. Paál Huba Dunaújvárosban érettségizett, egy évig raktári munkás volt, míg fel nem vették az ELTE Természettudományi Karának biológia-földrajz szakjára, ahol középiskolai tanári és szakbiológusi diplomát szerzett 1966-ban.

Különös biológus volt. Rengeteg kutatónak segített, hogy a karrierjük sikeressé váljon, de önmaga nem szerzett semmiféle tudományos fokozatot. Nem ér- 
dekelte saját dicsősége. Pedig kutatóként is tehetséges, kiváló alkotó volt. Sárkány Sándor professzor („Papi”, „Poppy”) mákkutatásába kapcsolódott be egyetemi éveiben. Kézügyessége, gyakorlati hozzáállása hamar kibontakozott. A mák embriológiai, embriófejlődési vizsgálataival hamar kitűnt a tanítványok közül, példaként emlegették az ELTE Alkalmazott Növénytani és Szövetfejlődéstani Intézet oktatói. A véget nem érő kutatás egy mákszem-embrió fejlődésének csodáiban tárult fel előtte! Az érdekes téma alkalmat adott számára, hogy ösztöndíjasként egy évet Indiában töltsön. Az Új-Delhiben lévő, világhírű Növényembriológiai Intézetben bővítette citológiai és embriológiai ismereteit. Itthon a botanikusok közül élénk szakmai kapcsolatot ápolt a Természettudományi Múzeum Növénytárában dolgozó neves citológus-taxonómus Ujhelyi Józseffel.

Nagy adománya életemnek, hogy megismerhettem és később barátomnak tudhattam. Szinte egy időben kezdtük kutatói pályánkat. Mindketten Tápiószelére, az Országos Agrobotanikai Intézetbe kerültünk Sárkány professzor javaslatára. Mándy György mellett kezdtük az agrobotanikai kutatást. Ez önmagában meghatározó hatással volt életünkre. Olyan tudós lett szellemi Mesterünk, aki a szakíráson kívül megtanított minket a lényegre látásra, feltárta számunkra a kultúrnövény-biológia legizgalmasabb kérdéseit. A genetikai, ökológiai és agrobotanikai szemléletet olyan kutatótól sajátíthattuk el, akit egyetemi tanári állásából azért függesztettek fel, mert kiállt a mendel-morgani genetika mellett, a liszenko-micsurini irányzattal szemben.

Paál Huba citológus lett. Magam a magvak csírázásbiológiájával kezdtem foglalkozni.

Paál Huba Pusztaszabolcsról utazott Tápiószelére, én Pécsről. A hosszú utakat, a huzamos távollét viszontagságait mindig követte a tápiószelei megérkezés: Mándy professzor (Gyurka bácsi) dolgozószobájának ablaka világított még késő este is, amikor a budapesti vonatról besétáltunk a Külsőmezőn fekvő régi kúriaépületig, az Intézetig. Késő éjjel is szakkönyveit és dolgozatait írta.

Felejthetetlen évek voltak... A régiek már emlékeinkbe vonultak: Jánossy Andor igazgató, később akadémikus, Mándy György, Boros Ádám, Koch Béla, Mesch József, Vinczeffy Imre, Pozsár Béla, Papp Erzsébet, Komlóssy György, Schmidt Gabriella, Holly László, Bányai László, Lun László, Székács Gabriella, Sajó Zoltán.

Paál Hubával szinte egy időben kerültünk otthonainkhoz közelebbi kutatóhelyre, Iregszemcsére, illetve Bicsérdre, az akkori Takarmánytermesztési Kutató Intézetbe. A napraforgó citológiai és fitokémiai kutatása különösen fontos volt a hibridnemesítés szempontjából. A bicsérdi laboratóriumok felszereltsége lehetővé tette az eredményes kutatást. Kurnik Ernő akadémikus nyugdíjaztatásával véget ért közös utunk. Attól kezdve a kommunista uralom, majd az azt követő privatizáció ennek az intézetnek is a végét jelentette, elsorvadt a kutatás, vetőmagtermesztő telephellyé vált a kutatóhely. 
Amikor Mándy professzor Debrecenbe került az Agrártudományi Egyetemre, megbízta, hogy citológiai kurzust tartson a Növénytani és Növényélettani Tanszéken. E célból gyakorlati jegyzet írásában is részt vett. Ugyancsak fejezetet írt az 1980-ban megjelent Magbiológia könyvbe a magvak anatómiai felépítéséről. A Magyarország kultúrflórája sorozatban anatómiai fejezetet írt a mézontófüről szóló monográfia-füzetbe. Részt vett a burgonya meriklónos szaporításának kidolgozásában, létrehozta a bicsérdi kutatóállomáson a növényi szövettenyésztési és citológiai laboratóriumot.

Kutatói időszakában írt publikációit külön listában közöljük.

Az 1980-as évek közepétől az MTA Központi Hivatala tanácsosa, majd fötanácsosa lett. A Regionális Kutatások Központjának igazgatójaként országos szinten irányította az MTA kutatócsoportok munkáját. A bölcsességet és széles látókört kívánó feladat ellátásában sokat jelentett kutatóintézeti múltja. Sok akadémiai kutatócsoport neki köszönhette megmaradását és eredményes tevékenységét.

Közéleti karrierje Pusztaszabolcson indult, amikor az 1990-es önkormányzati választások során képviselőtestületi tag lett, majd ugyanez év decemberében Fejér Megye Közgyülésének elnökévé választották. Megyei választmányi elnöke volt az MDF-nek. Áldozatos és eredményes harcot vívott a megye fejlődéséért. Szűkebb hazájának becsületes szolgálata elismeréséül megkapta a „Pusztaszabolcs díszpolgára" címet.

A Magyar Biológiai Társaság Pécsi Csoportjának egyik alapító tagját, a Magyar Biológiai Társaság Botanikai Szakosztályának lelkes látogatóját, a felkészült biológus kutatót, a kiváló tudományszervezőt és Fejér megye polgárainak Szolgálóját veszítettük el. Emlékét őrizzük.

\section{Köszönetnyilvánítás}

Hálás köszönetemet fejezem ki Szabó István professzornak, aki az emlékezés megírására biztatott és segítséget nyújtott egyes életrajzi adatokkal. Abban, hogy Szabó István a keszthelyi Növénytani és Növényélettani Tanszéken néhai Kárpáti István professzort követte tanszékvezető egyetemi tanárként, nagy szerepe volt a kezdetnek: fiatalon, még egyetemistaként megismerte Boros Ádámot, s a tápiószelei fiatal kutatókat, köztük Paál Hubát és e sorok íróját. Kialakult baráti és kollegiális kapcsolatunk legszebb emlékeink között maradt máig is.

\section{Paál Huba botanikai munkássága*}

Paál H. 1966: Néhány paradicsomfajta epicarpiumának vizsgálata. Agrobotanika 8: 127-134.

Paál H., Sárkány S., Gracza P. 1966: Einige Beobachtungen über die Bildung und Anfangsorganisation des Endosperms von Papaver somniferum L. II. Magyar Növényanatómiai Szimpózium, 1966. szeptember 6-8., Budapest.

\footnotetext{
* Összeállította: Kalapos Tibor
} 
Paál H., Szabó L. 1967: A klórkolinklorid (CCC) hatása a búza szárának szöveti szerkezetére. Agrobotanika 9: 171-180.

Sulyok I., Paál H., Szabó L. 1967: Fitohormonok hatása a lucerna járulékos gyökérképződésére. Agrobotanika 9: 137-142.

Lun L., Paál H. 1968: Hímsteril paradicsom vizsgálatok II. Agrobotanika 10: 101-109.

Paál H. 1968: A herefajok kromoszóma-viszonyai. In: Mándy Gy. (szerk.) Herefajok termesztése és nemesítése. Akadémiai Kiadó, Budapest, pp. 39-49.

Paál H. 1968: A herefajok belső alaktana (anatómiája). In: Mándy Gy. (szerk.) Herefajok termesztése és nemesítése. Akadémiai Kiadó, Budapest, pp. 97-119.

Szücs Á., Paál H. 1968: Néhány zöldfogyasztású babfajta agrobotanikai vizsgálata. Agrobotanika 10: 227-240.

Paál H., Gracza P. 1969: Contributions to the seed development of field poppy (Papaver rhoeas L.). Acta Agronomica Academiae Scientiarum Hungaricae 18: 387-390.

Mándy Gy., Pankucsi L.-né, Paál H. 1971: Mezőgazdasági növénytani gyakorlatok I. Egyetemi jegyzet. Agrártudományi Egyetem, Növénytani és Növényélettani Tanszék, Debrecen, 141 pp.

Paál H. 1971: A Vicia-fajok kromoszóma-viszonyai. In: Mándy Gy. (szerk.) A Vicia-fajok termesztése és nemesítése. Akadémiai Kiadó, Budapest, pp. 44-52.

Paál H. 1971: A Vicia-fajok belső alaktana. In: Mándy Gy. (szerk.) A Vicia-fajok termesztése és nemesítése. Akadémiai Kiadó, Budapest, pp. 65-83.

Paál H., Mándy Gy. 1971: A lencse kromoszómaviszonyai és örökléstana. In: Mándy Gy., Kiss B. A lencse - Lens culinaris Medik. Magyarország kultúrflórája 33. Akadémiai Kiadó, Budapest, p. 58.

Heszky L., Paál H. 1972: Haploid növények felnevelése pollenekből a Nicotiana tabacum L. portokkultúrájában. Botanikai Közlemények 59(2): 125-127. + 2 tábla

Gallai Gy.-né, Horváth I., Máthé P., Paál H. 1974: A bab (Phaseolus vulgaris L.) magvak peroxidázának vizsgálata a csírázás folyamán. Agrobotanika 16: 177-183.

Kiss Á., Paál H. 1974: In vivo pollentömlő-növekedési vizsgálatok paprikánál (Capsicum annuum L.). Agrobotanika 16: 89-95.

Paál H. 1975: A mézontófü kromoszómaszáma. In: Boros Á. A mézontófü - Phacelia tanacetifolia Benth. Magyarország kultúrflórája 40. Akadémiai Kiadó, Budapest, p. 9.

Paál H., Szabó L. 1975: A mézontófü belső alaktana. In: Boros Á. A mézontófü - Phacelia tanacetifolia Benth. Magyarország kultúrflórája 40. Akadémiai Kiadó, Budapest, pp. 16-25.

Paál H. 1978: Emlékezés Mándy Györgyre. Botanikai Közlemények 65(1): 1-2.

Paál H., Szabó L., Pozsár B. 1979: Hajtásdekapitálás hatása a szója kezdeti fejlődésére I. Változások a szár szöveti szerkezetében. Botanikai Közlemények 66(2-4): 121-125.

Paál H. 1980: A borsó citológiai jellemzői. In: Mándy Gy., Szabó L., Ács A.: A borsó - Pisum sativum L. Magyarország kultúrflórája 49. Akadémiai Kiadó, Budapest, pp. 19-22.

Paál H. 1980: A borsó genetikai viszonyai. In: Mándy Gy., Szabó L., Ács A.: A borsó - Pisum sativum L. Magyarország kultúrflórája 49. Akadémiai Kiadó, Budapest, pp. 102-109.

Paál H. 1980: A mag fejlődése és szöveti szerveződése. In: Szabó L. Gy. (szerk.) A magbiológia alapjai. Akadémiai Kiadó, Budapest, pp. 13-60.

Paál H., Rudolf J., Pozsár B., Szabó L. 1980: Burgonya alapanyag fenntartása a fényhajtások nodális szegmentjeinek in vitro tenyésztésével. Botanikai Közlemények 67(2): 103-111.

Paál H., Kurnik E., Szabó L. 1981: Napraforgó növény-regeneráció in vitro hajtáscsúcs-tenyészetből. Növénytermelés 30(3): 201-208.

Paál H., Szabó L. 1981: Hajtáscsúcs-tenyészetek jelentősége a napraforgó-nemesítésben. Pécsi Müszaki Szemle 26(2): 15-16.

Praznovszky T., Kurnik E., Paál H., Dudits D. 1981: Sejthibridizációs kísérletek szója és borsó protoplasztok fúziójával. Biológia 29: 213-218. 
Mostafa R. M., Kováts Z., Gracza P., Paál H., Fridvalszky L. 1982: A kallusz és gyökér fejlődése, szövetes alakulása néhány egynyári virág portokkultúrájában. Agrártudományi Közlemények 41: 251 .

Paál H. 1982: A zab citogenetikája. In: Szabó L. A zab - Avena sativa L. Magyarország kultúrflórája 52. Akadémiai Kiadó, Budapest, pp. 26-32.

Paál H. 1982: A zab örökléstana. In: Szabó L. A zab - Avena sativa L. Magyarország kultúrflórája 52. Akadémiai Kiadó, Budapest, pp. 122-127.

Paál H., Bányai D., Balatincz Zs., Kurnik E. 1982: Korai szívstádiumú borsóembriók in vitro morfogenetikai képessége. Agrártudományi Közlemények 41: 249.

Paál H., Kurnik E., Szabó L. 1982: In vitro növényregeneráció napraforgó hajtáscsúcsból. Agrártudományi Közlemények 41: 256.

Paál H., Szabó L., Rudolf J., Pozsár B. 1982: Desiree burgonyafajta meriklónozása nodális szegmentekből. Agrártudományi Közlemények 41: 240.

Praznovszky T., Dudits D., Kurnik E., Paál H. 1982: Sejthibridizációs kísérletek szója és borsó protoplasztok fúziójával. Agrártudományi Közlemények 41: 212.

Wolf I., Kölber M., Paál H., Vágner Cs., Pácsa S. 1985: Néhány burgonyavírus kimutatása szövettenyésztéssel előállított növényekben Elisa-eljárással. Növényvédelem 21(7): 304-305.

Sárkány S., Paál H., Bernáth J. 2001: A mák fejlődésalaktana, fenológiája, virágzás- és termésbiológiai viszonyai. In: Sárkány S., Bernáth J., Tétényi P.: A mák - Papaver somniferum L. Magyarország kultúrflórája 71. Akadémiai Kiadó, Budapest, pp. 105-112.

Paál H. 2014: Mándy György professzor születésének centenáriumán. Botanikai Közlemények 101(1-2): 31-32.

Paál H., Surányi D., Szabó L. Gy. 2015: Emlékezés Holly Lászlóra (1943-2015). Botanikai Közlemények 102(1-2): 1-18.

Paál H., Kota M., Szabó L. Gy. 2018: Emlékezés Vinczeffy Imrére, a magyar gyepkutatás kiemelkedő alakjára. Botanikai Közlemények 105(1): 1-12.

\title{
Remembering Huba Paál (1942-2021)
}

\author{
L. Gy. SZABÓ \\ H-7623 Pécs, Semmelweis u. 11, Hungary; szabol@gamma.ttk.pte.hu
}

Accepted: 5 November 2021

Key words: agrobotany, cytology, science management, Tápiószele

Huba Paál, an excellent researcher and selfless aide of numerous scientists passed away on 16 October 2021. He was born in Lajosmizse on 14 May 1942. He graduated from the Eötvös Loránd University as a biologist and biology-geography high school teacher in 1966. He started his career in the laboratory of Prof. Sándor Sárkány on the embryology of cultivated poppy. His outstanding activity resulted in a one-year scholarship to the Plant Embryological Institute in New 
Delhi, India. Then he joined the Agrobotanical Research Institute in Tápiószele, where he became a renowned cytologist in the group of Prof. György Mándy. The years spent in Tápiószele and later in the Forage Research Institute in Iregszemcse was the scientifically most productive period of his life. He published extensively and helped many of his fellow researchers selflessly in their work. He participated in the development of mericlonal propagation of potato, and established a plant tissue culture and cytology laboratory at the Bicsérd research station. Since the mid-1980s, he took a leading position in the central administration of the Hungarian Academy of Sciences, where his task was the coordination of research conducted in the academic research groups throughout Hungary. Since 1990, he got involved into public administration and soon as an elected President of the Fejér County Assembly served the society. He was an active member of the Hungarian Biological Society and maintained his keen interest in botany even during the years of public service. We keep his memory. 